\title{
Graphene/CuS/PbS nanocomposite as an effective counter electrode for quantum dot sensitized solar cells
}

\author{
Mahmoud Samadpour*a, Shaghayegh Arabzade ${ }^{\mathrm{a}}$
}

\begin{abstract}
:
In this paper, we introduce graphene/ $\mathrm{CuS} / \mathrm{PbS}$ nanocomposite as an effective counter electrode (CE) for quantum dot sensitized solar cells (QDSCs). The result indicated that the catalytic performance of $\mathrm{CuS} / \mathrm{PbS} \mathrm{CEs}$ was enhanced by pre deposition of graphene (G) sheets on the fluorine doped tin oxide (FTO) coated glass substrates. Here, various CEs are made by the simple successive ionic layer adsorption and reaction (SILAR) method. The result indicates that the fill factor of the cells with FTO/G/CuS/PbS CEs enhances in compare with the FTO/CuS/PbS CEs. Here, for the $\mathrm{CdS} / \mathrm{CdSe}$ QD sensitized cells and G/CuS/PbS CEs, the cells' efficiency and fill factor is obtained $3.21 \%$ and 0.51 respectively which is enhanced compared to the $\mathrm{CuS} / \mathrm{PbS}$ CEs with $2.54 \%$ efficiency and 0.36 fill factor. The present results indicate that the compact structure of the $\mathrm{CuS} / \mathrm{PbS} \mathrm{CEs}$, replaces with a porous structure after graphene pre deposition which is expected to enhance the electrolyte/CE interface and consequently the fill factor. According to the obtained results, in spite of the poor catalytic activity of the graphene in the polysulfide electrolyte, it simply modifies the morphology of the $\mathrm{CuS} / \mathrm{PbS} \mathrm{CEs}$ for enhancing their performance. The results also demonstrated that $G$ pre deposition can be systematically applied to enhance the performance of CEs in QDSCs.
\end{abstract}


1 Key words: quantum dot, solar cell, counter electrode, graphene, SILAR, fill factor

\section{1. Introduction}

4 Currently solution processed semiconductor nanocrystals are promising for 5 making low cost, large scale and efficient quantum dot solar cells [1-10]. 6 Optoelectronical properties of semiconductor quantum dots could simply tailored by 7 controlling their size, shape and other synthesizing parameters. QDs show high 8 extinction coefficients, large dipole moments and also multiple exciton generation under 9 specified conditions [11, 13]. Recently, considerable research is conducted on all 10 components of QDSCs containing photoanode, electrolyte and counter electrode in 11 order to enhancing the QDSCs photovoltaic properties. For example one dimensional 12 photoanode structures such as nanorods, wire and tubes are sensitized with QDs in order 13 to improve the charge transport in the photoanode structure [14-17]. Chemical 14 composition of the redox electrolytes is optimized and tens of different cathode 15 electrodes are applied in QDSCs [18-20]. Regarding the mentioned optimizations 16 currently the efficiency of QDSCs is boosted more than $8 \%$ which is interesting [21, 17 22]. Literature review indicates that the open circuit voltages [23] and current densities 18 [24] of QDSCs have improved noticeably in the last few years. However, the typical energy conversion efficiencies of QDSCs are still lower than dye sensitized solar cells

20 (DSCs) which are mainly originated by the low fill factors in QDSCs. The fill factor in 21 QDSCs is generally less than 0.6 (fill factors of $0.75-0.8$ is simply obtained in DSCs) 22 which restricts the further efficiency enhancements [25, 28]. According to the previous 23 researches, reducing the series resistance of the $\mathrm{CE}$ and improving the charge transfer 24 kinetics at the CE/electrolyte interface clearly improves the fill factor [29- 31]. Until 
1 now, various $\mathrm{CEs}$ like $\mathrm{Pt}, \mathrm{Au}, \mathrm{PbS}, \mathrm{CuS}, \mathrm{CoS}, \mathrm{CuS} / \mathrm{PbS}$, graphite, carbon black, carbon

2 nanotubes, and graphene are utilized in QDSCs [32-38]. Among the mentioned CEs,

3 metal sulfides such as $\mathrm{CuS}, \mathrm{CoS}, \mathrm{PbS}$ and their composition like $\mathrm{CuS} / \mathrm{PbS}$ have

4 generally a better catalytic performance and stability in the polysulfide redox electrolyte

5 which is generally used in QDSCs [39-41]. Currently the chemical treatment of the

6 metallic brass and $\mathrm{Pb}$ substrates is generally utilized in order to make $\mathrm{CuS}$ and $\mathrm{PbS} \mathrm{CEs}$

7 respectively [39-41]. Metallic based CEs have a suitable porous structure with moderate

8 catalytic properties [40-43]. However sealing these metallic CEs with the photoanode

9 which is prepared on the FTO coated glass substrate is a challenge. Regarding the

10 challenges of metallic based CEs, recently various $\mathrm{CEs}$ like $\mathrm{CuS}, \mathrm{PbS}$ and $\mathrm{CoS}$ are

11 prepared on the FTO coated glass substrates by SILAR method [1, 31, 43-45]. SILAR

12 method is simple, cost effective, and suitable for large scale production. Also most

13 importantly is easy for sealing the cells without electrolyte leakage. Regarding the

14 simple procedure of SILAR method, recently various nanocomposite cathode electrodes

15 like $\mathrm{CoS} / \mathrm{CuS}, \mathrm{CuS} / \mathrm{PbS}$ are developed and enhanced the catalytic performance of the

16 bare $\mathrm{CuS}, \mathrm{PbS}$ and $\mathrm{CoS} \mathrm{CEs}[10,31,45]$. In spite of the interesting properties of SILAR

17 deposited CEs on FTO coated glass substrates, these cathode electrodes have a compact

18 structure in comparison to the CEs which are made on metallic substrates. The compact

19 structure of the $\mathrm{CE}$ limits the $\mathrm{CE} /$ electrolyte interface which consequently restricts the

20 charge transfer at $\mathrm{CE} /$ electrolyte interface [10]. Restricted charge transfer at the

$21 \mathrm{CE} /$ Electrolyte interface, accumulates space charges and therefore diminish the fill

22 factor considerably [41, 46-47].

23 Here we show that graphene pre deposition on the FTO coated glass substrate could

24 simply modify the compact structure of the SILAR deposited CuS/PbS CEs to a more 
1 porous structure. For the $\mathrm{CdS} / \mathrm{CdSe}$ QD sensitized cells and FTO/G/CuS/PbS CEs, the

2 cell performance with $3.21 \%\left(\mathrm{~V}_{\mathrm{oc}}=550 \mathrm{mV}, \mathrm{J}_{\mathrm{sc}}=11.43 \mathrm{~mA} / \mathrm{cm}^{2}, \mathrm{FF}=0.51\right)$ efficiency was

3 obtained which was enhanced in comparison with the photovoltaic properties of the cells

4 with normal FTO/CuS/PbS CEs with $2.54 \%$ efficiency $\left(\mathrm{V}_{\mathrm{oc}}=526 \mathrm{mV}, \mathrm{J}_{\mathrm{sc}}=13.4 \mathrm{~mA} / \mathrm{cm}^{2}\right.$,

$5 \quad \mathrm{FF}=0.36$ ). Especially the fill factor of the cells is improved by graphene pre deposition

6 on the FTO substrates. The present general study indicated that the G pre deposition

7 could offer a simple systematic method for improving the performance of the solution-

8 processed CEs with noticeable catalytic activity in polysulfide redox electrolytes.

\section{2. Experimental methods}

112.1 Photoanode preparation. Photoanodes are made of a transparent and also an opaque

$12 \mathrm{TiO}_{2}$ layer. Transparent layer was deposited from a paste with $20-30 \mathrm{~nm}$ nanoparticle

13 sizes [48]. Opaque layers are made from a paste with $20-400 \mathrm{~nm}$ core-shell of $\mathrm{TiO}_{2}-\mathrm{SiO}_{2}$

14 nanoparticles and were deposited on the transparent layer as the light scattering layer

15 [49]. All the Photoanodes were annealed at $450^{\circ} \mathrm{C}$ for $45 \mathrm{~min}$ in order to enhancing their

16 electrical properties. $\mathrm{TiO}_{2}$ photoanodes were sensitized by $\mathrm{CdS} / \mathrm{CdSe} / \mathrm{ZnS}$ QDs using

17 SILAR and chemical bath deposition (CBD) methods. CdS QDs were deposited by the

18 SILAR method [50]. Here, $\mathrm{Cd}^{2+}$ precursor were prepared from a $0.05 \mathrm{M}$ ethanolic

19 solution of $\mathrm{Cd}\left(\mathrm{NO}_{3}\right)_{2} \cdot 4 \mathrm{H}_{2} \mathrm{O}$ and sulfide source was a $0.05 \mathrm{M}$ solution of $\mathrm{Na}_{2} \mathrm{~S} .9 \mathrm{H}_{2} \mathrm{O}$ in

20 methanol/water $(50 / 50 \mathrm{~V} / \mathrm{V}) . \mathrm{TiO}_{2}$ electrodes were put into the $\mathrm{Cd}^{2+}$ precursor, and

21 subsequently, into the $\mathrm{S}^{2-}$ solution for both $1 \mathrm{~min}$ (this is termed a single SILAR cycle).

22 After each precursor bath, the photoanode was dipped into the corresponding solvent to

23 remove the chemical residuals and then dried by an air gun. CdSe QDs were deposited

24 by the CBDmethod [50]. A chemical bath was made by mixing $80 \mathrm{mM}$ of $\mathrm{Na}_{2} \mathrm{SeSO}_{3}$ 
1 and $\mathrm{CdSO}_{4}$ with $120 \mathrm{mM}$ of nitrilotriacetic acid sodium salt. $\mathrm{Na}_{2} \mathrm{SeSO}_{3}$ solution was

2 made by refluxing Se and $\mathrm{Na}_{2} \mathrm{SO}_{3}$ powders in Milli-Q water at $80{ }^{\circ} \mathrm{C}$. $\mathrm{CdS}$ sensitized

$3 \mathrm{TiO}_{2}$ working electrodes were put in the bath solution at $10{ }^{\circ} \mathrm{C}$ for $12 \mathrm{~h}$. Finally, $\mathrm{ZnS}$

4 was coated on $\mathrm{CdS} / \mathrm{CdSe} \mathrm{TiO}_{2}$ sensitized electrodes by two SILAR cycles according to

5 the previously described method [51]. It is generally known that $\mathrm{ZnS}$ improves the

6 performance of QDSCs by reducing the recombination and enhancing the stability of the 7 cells [51].

92.2 CEs preparation. CEs were made by SILAR method. CuS layers were made from $10 \mathrm{Cu}\left(\mathrm{NO}_{3}\right)_{2} \cdot 3 \mathrm{H}_{2} \mathrm{O}$ and $\mathrm{Na}_{2} \mathrm{~S} .9 \mathrm{H}_{2} \mathrm{O}$ precursors. $\mathrm{Cu}^{2+}$ ions were deposited from a $0.5 \mathrm{M}$ 11 aqueous solution of $\mathrm{Cu}\left(\mathrm{NO}_{3}\right)_{2} .3 \mathrm{H}_{2} \mathrm{O}$ and $\mathrm{S}^{2-}$ sources were the $0.5 \mathrm{M}$ solution of $\mathrm{Na}_{2} \mathrm{~S} .9$ $12 \mathrm{H}_{2} \mathrm{O}$ in methanol/water $(50 / 50 \mathrm{~V} / \mathrm{V}) . \mathrm{CuS}$ deposition consisted of 1 min dip-coating of 13 the FTO substrate into the metal precursor and subsequently into the sulfide solution for $141 \mathrm{~min}$ (termed as a single SILAR cycle). After each $\mathrm{Cu}^{2+}$ and $\mathrm{S}^{2-}$ precursor bath, the 15 photoanode was rinsed by the corresponding solvent and then dried by an air gun. For 16 the $\mathrm{PbS}$ deposition, a $0.02 \mathrm{M}$ methanolic solution of $\mathrm{Pb}\left(\mathrm{NO}_{3}\right)_{2} .4 \mathrm{H}_{2} \mathrm{O}$ and a $0.02 \mathrm{M}$ 17 solution of $\mathrm{Na}_{2} \mathrm{~S} .9 \mathrm{H}_{2} \mathrm{O}$ in methanol/water $(50 / 50 \mathrm{~V} / \mathrm{V})$ were used as $\mathrm{Pb}^{2+}$ and $\mathrm{S}^{2-}$ ions 18 respectively. FTO coated glass substrates subsequently dip coated into the $\mathrm{Pb}^{2+}$ and $\mathrm{S}^{2-}$ 19 precursors for $1 \mathrm{~min}$ (a single SILAR cycle). After each bath, photoanodes were rinsed 20 by the corresponding solvent and then dried.

21 In order to make $\mathrm{G} / \mathrm{CuS} / \mathrm{PbS} \mathrm{CEs}$, graphene sheets were prepared from natural 22 graphite powder by a modified Hummers' method as we described before [25]. 23 Graphene suspension $(0.5 \mathrm{mg} / \mathrm{ml})$ spin coated with $2000 \mathrm{rpm}$ on FTO substrates. After 24 each spin coating, samples were put in an oven at $100{ }^{0} \mathrm{C}$ for 5 minutes in order to dry 
1 the deposited layers. Spin coating process was repeated for 1-12 times in order to make

2 various structures of CEs. G/CuS/PbS CEs were prepared by deposition of $\mathrm{CuS}$ and $\mathrm{PbS}$

3 layers on the graphene pre coated FTO substrates by SILAR method as described above.

$4 \mathrm{CuS}$ CEs were also prepared on the metallic substrates for comparison their structure

5 with SILAR deposited CEs. The CuS counter electrodes were prepared by immersing

6 brass substrates in $\mathrm{HCl}$ solution at $70^{\circ} \mathrm{C}$ for $10 \mathrm{~min}$ and subsequently dipping it into the 7 polysulfide solution for $3 \mathrm{~min}$.

92.3 QDSC preparation. The sensitized photoelectrodes and CEs were sealed by means of 10 a Surlyn spacer (thickness 30 microns). Polysulfide electrolyte was contained $1 \mathrm{M}$ $11 \mathrm{Na}_{2} \mathrm{~S}, 1 \mathrm{M} \mathrm{S}$, and $0.1 \mathrm{M} \mathrm{NaOH}$ solution in Milli-Q ultrapure water. Area of the cells was $12 \quad 0.25 \mathrm{~cm}^{2}$.

142.4 Photoanode and solar cell characterization. J-V measurements were carried out by 15 PGSTAT-30 from Autolab Company. Cells were illuminated using a solar simulator at 16 AM1.5 G, and the light power was adjusted to $100 \mathrm{~mW} / \mathrm{cm}^{2}$.

\section{3. Results and discussion}

19 SEM micrograph from the transparent $\mathrm{TiO}_{2}$ layer which is deposited on the FTO substrates is indicated in Figure 1a. According to this figure, $\mathrm{TiO}_{2}$ layer contains $20-40$

$21 \mathrm{~nm}$ particle sizes which prepare enough surface area for the QDs sensitizer deposition.

22 Figure $1 \mathrm{~b}$ shows the SEM micrograph from the scattering layer with $20-400 \mathrm{~nm}$ particle 23 sizes that is deposited on the first transparent layer.

Figure 1. 
1 Before making $\mathrm{G} / \mathrm{CuS} / \mathrm{PbS}$ CEs structures, we first optimized the number of graphene

2 spin coating by making simple G/PbS CEs structures. First category of the cells was

3 made by pre deposition of graphene on the FTO substrates with various numbers of spin

4 coating (from 1 to 12 times) and then depositing the $\mathrm{PbS}$ on the graphene coated FTO

5 substrates by 6 SILAR cycles. Figure 2 indicates the SEM micrograph of graphene

6 sheets on the FTO coated glass substrate. From this figure it could be seen that graphene

7 sheets distorts the uniform topology of the FTO substrates as indicated by arrows inset

8 the figure. This non uniformity could potentially change the kinetic of the $\mathrm{PbS}$

9 deposition on the FTO/G substrate relative to its deposition on the bare FTO substrates.

Figure 2.

11 Figure 3 indicates the current-voltage properties of $\mathrm{CdS} / \mathrm{CdSe}$ sensitized cells which are made by G/PbS CEs under light illumination (figure 3a) and dark conditions (figure 3b).

13 In this Figure the number of spin coating of graphene layer and number of SILAR 14 cycles for $\mathrm{PbS}$ deposition are indicated in parentheses against the $\mathrm{G}$ and $\mathrm{PbS}$. For example $\mathrm{G}(2) / \mathrm{PbS}(6 \mathrm{~S})$ means that graphene has been deposited by two times spin coating and then $\mathrm{PbS}$ is deposited on graphene by 6 SILAR cycles. According to this

17 figure, noticeable difference is not observed in the current voltage properties of the cells 18 with various number of $\mathrm{G}$ deposited layers. In order to have more accurate comparison 19 of photovoltaic parameters, open circuit voltage $\left(\mathrm{V}_{\text {oc }}\right)$, short circuit current density $\left(\mathrm{J}_{\mathrm{sc}}\right)$, 20 fill factor (FF), and conversion efficiency (E) of QDSCs, are shown in Table 1.

Figure 3 .

22 Table 1: Photovoltaic parameters of the QDSCs: photocurrent $j_{s c}$, open circuit voltage $V_{o c}$, fill factor $F F$, 23 and efficiency $E$, as a function of the CEs structure tested under standard conditions $\left(100 \mathrm{~mW} / \mathrm{cm}^{2} \mathrm{AM}\right.$

\begin{tabular}{lllll}
\hline Cathode Type & $\mathrm{V}_{\mathrm{oc}}(\mathrm{mV})$ & $\mathrm{J}_{\mathrm{sc}}\left(\mathrm{mA} / \mathrm{cm}^{2}\right)$ & $\mathrm{FF}$ & $\mathrm{E}(\%)$
\end{tabular}




\begin{tabular}{ccccc}
\hline $\mathrm{G}(1) / \mathrm{PbS}(6 \mathrm{~S})$ & 532 & 9.41 & 0.41 & 2.05 \\
$\mathrm{G}(2) / \mathrm{PbS}(6 \mathrm{~S})$ & 529 & 8.62 & 0.47 & 2.14 \\
$\mathrm{G}(4) / \mathrm{PbS}(6 \mathrm{~S})$ & 510 & 7.30 & 0.41 & 1.52 \\
$\mathrm{G}(6) / \mathrm{PbS}(6 \mathrm{~S})$ & 539 & 8.55 & 0.44 & 2.03 \\
$\mathrm{G}(8) / \mathrm{PbS}(6 \mathrm{~S})$ & 524 & 7.97 & 0.51 & 2.13 \\
$\mathrm{G}(10) / \mathrm{PbS}(6 \mathrm{~S})$ & 532 & 8.91 & 0.45 & 2.13 \\
$\mathrm{G}(12) / \mathrm{PbS}(6 \mathrm{~S})$ & 529 & 8.74 & 0.45 & 2.08 \\
& & & & \\
\hline
\end{tabular}

1

2 As can be seen in this table, the efficiency of the cells with $\mathrm{G}(1) / \mathrm{PbS}(6 \mathrm{~S}) \mathrm{CEs}(2.05 \%)$

3 is improved to $2.14 \%$ in $\mathrm{G}(2) / \mathrm{PbS}(6 \mathrm{~S})$ CEs. Regarding this little efficiency

4 improvement by increasing the number of $\mathrm{G}$ layers, graphene spin coating process was

5 repeated for 12 times. According to Table 1, efficiency is not improved any more by

6 increasing the number of graphene deposited layers from 4 to 12 and the best efficiency

7 was obtained $2.13 \%$ for $\mathrm{G}(8) / \mathrm{PbS}(6 \mathrm{~S})$ and $\mathrm{G}(10) / \mathrm{PbS}(6 \mathrm{~S})$ CEs which is almost same

8 by $\mathrm{G}(2) / \mathrm{PbS}(6 \mathrm{~S}) \mathrm{CEs}(2.14 \%)$. Also the efficiency of the cells with $6,8,10$ and 12

9 layers of graphene and the same number of SILAR deposited PbS layer is very similar

10 (from 2.03 to $2.13 \%$ ). This result indicates that $\mathrm{PbS}$ is mainly responsible for the

11 catalytic properties of the $\mathrm{G} / \mathrm{PbS}$ nanocomposite $\mathrm{CEs}$ and increasing the number of $\mathrm{G}$

12 spin coatings more than 2 times, has no beneficial effect (Table 1). Regarding the unique

13 properties of the graphene structures, stability of the electrodes was investigated under

14 aging in room temperature from 0 to 72 hours. Here we applied Graphene/PbS as

15 counter electrodes and $\mathrm{TiO}_{2}$ was sensitized by $\mathrm{CdS} / \mathrm{CdSe}$ QDs. Photovoltaic parameters

16 of QDSCs, containing: open circuit voltage $\left(\mathrm{V}_{\mathrm{oc}}\right)$, short circuit current density $\left(\mathrm{J}_{\mathrm{sc}}\right)$, fill

17 factor (FF), and conversion efficiency (E) are shown in Table 2.

19 Table 2: Photovoltaic parameters of the QDSCs prepared and analyzed: photocurrent $j_{s c}$, open circuit 
1 voltage $V_{o c}$, fill factor $F F$, and efficiency $E$, as a function of aging time.

\begin{tabular}{ccccc}
\hline Aging time $(\mathrm{h})$ & $\mathrm{V}_{\mathrm{oc}}(\mathrm{mv})$ & $\mathrm{J}_{\mathrm{sc}}\left(\mathrm{mA} / \mathrm{cm}^{2}\right)$ & $\mathrm{FF}$ & $\mathrm{E}$ \\
\hline 0 & 503 & 8.95 & 0.47 & 2.11 \\
24 & 524 & 9.39 & 0.47 & 2.31 \\
48 & 525 & 8.61 & 0.45 & 2.03 \\
72 & 511 & 8.51 & 0.44 & 1.91 \\
\hline
\end{tabular}

2

3 According to this table, the as prepared cells showed an energy conversion efficiency of

$42.11 \%$ and $\mathrm{V}_{\mathrm{oc}}, \mathrm{J}_{\mathrm{sc}}$ and efficiency was found to have enhanced after 24 hours aging $5\left(\mathrm{E}=2.31 \%, \mathrm{~V}_{\mathrm{oc}}=524 \mathrm{mV}, \mathrm{J}_{\mathrm{sc}}=9.39 \mathrm{~mA} / \mathrm{cm}^{2}, \mathrm{FF}=0.47\right)$. This improvement could be 6 related to the enhanced electrolyte diffusion into the porous structure of the CEs by 7 aging. Also the efficiency of the cells is reached to $90 \%$ (1.91\%) of their initial value $8(2.11 \%)$ which is considerable. The present results, indicates that graphene structures 9 have considerable stability in the polysulfide electrolyte and even more stable cells 10 could be prepared by improving the sealing quality.

11 Current-voltage properties of $\mathrm{CdS} / \mathrm{CdSe}$ sensitized cells which are made by $\mathrm{G}, \mathrm{PbS}$ and $12 \mathrm{G} / \mathrm{PbS}$ CEs is presented in figure 4 and table 3 for comparison.

Figure 4.

14 Table 3: Photovoltaic parameters of the QDSCs prepared and analyzed: photocurrent $j_{s c}$, open circuit voltage $V_{o c}$, fill factor $F F$, and efficiency $E$, as a function of the CEs structure

\begin{tabular}{ccccc}
\hline Cathode Type & $\mathrm{V}_{\mathrm{oc}}(\mathrm{mV})$ & $\mathrm{J}_{\mathrm{sc}}\left(\mathrm{mA} / \mathrm{cm}^{2}\right)$ & $\mathrm{FF}$ & $\mathrm{E}(\%)$ \\
\hline $\mathrm{G}(2)$ & 464 & 2.38 & 0.23 & 0.25 \\
$\mathrm{PbS}(6 \mathrm{~S})$ & 515 & 12.99 & 0.20 & 1.34 \\
$\mathrm{G}(2) / \mathrm{PbS}(6 \mathrm{~S})$ & 529 & 8.62 & 0.47 & 2.14
\end{tabular}

17 From the results in the Table 3, the beneficial effect of G pre deposition on the FTO 18 substrate is clearly observed specially on the fill factor, resulting in more efficiency to 
1 be obtained.

2 The second category of the cells was made by deposition of $\mathrm{CuS} / \mathrm{PbS} / . . / \mathrm{CuS} / \mathrm{PbS} \mathrm{CEs}$

3 [10]. Here $\mathrm{CuS} / \mathrm{PbS} / . . . / \mathrm{CuS} / \mathrm{PbS}$ CEs were made by 6 to 12 cycles of SILAR deposition

4 in order to optimize the CE structure.

5 Figure 5 indicates the current-voltage properties of the cells which are made by 6 deposition of $\mathrm{CuS} / \mathrm{PbS} / . . / \mathrm{CuS} / \mathrm{PbS} \mathrm{CEs}$ under light illumination (figure 5a) and dark 7 conditions (figure 5b). Here the numbers of the SILAR cycles are indicated in 8 parentheses against. For example: $\mathrm{CuS} / \mathrm{PbS} / . . / \mathrm{CuS} / \mathrm{PbS}(6 \mathrm{~S})$ means that $\mathrm{CuS}$ and $\mathrm{PbS}$ 9 layers are deposited one by one and totally for 6 cycles.

11 In order to have more accurate comparison of the results, open circuit voltage $\left(\mathrm{V}_{\mathrm{oc}}\right)$, 12 short circuit current density $\left(\mathrm{J}_{\mathrm{sc}}\right)$, fill factor $(\mathrm{FF})$, and conversion efficiency $(\mathrm{E})$ are 13 shown in Table 4.

Table 4: Photovoltaic parameters of the QDSCs prepared and analyzed: photocurrent $j_{s c}$, open circuit voltage $V_{o c}$, fill factor $F F$, and efficiency $E$, as a function of the CEs structure.

\begin{tabular}{ccccc}
\hline Cathode Type & $\mathrm{V}_{\mathrm{oc}}(\mathrm{mV})$ & $\mathrm{J}_{\mathrm{sc}}\left(\mathrm{mA} / \mathrm{cm}^{2}\right)$ & $\mathrm{FF}$ & $\mathrm{E}(\%)$ \\
\hline $\mathrm{CuS} / \mathrm{PbS} / \ldots / \mathrm{CuS} / \mathrm{PbS}(6 \mathrm{~S})$ & 520 & 10.82 & 0.34 & 1.91 \\
$\mathrm{CuS} / \mathrm{PbS} / \ldots / \mathrm{CuS} / \mathrm{PbS}(8 \mathrm{~S})$ & 526 & 13.4 & 0.36 & 2.54 \\
$\mathrm{CuS} / \mathrm{PbS} / \ldots / \mathrm{CuS} / \mathrm{PbS}(10 \mathrm{~S})$ & 510 & 9.73 & 0.42 & 2.08 \\
$\mathrm{CuS} / \mathrm{PbS} / \ldots / \mathrm{CuS} / \mathrm{PbS}(12 \mathrm{~S})$ & 420 & 7.55 & 0.36 & 1.14 \\
& & & & \\
\hline
\end{tabular}

17

18 Here the best performance of the cells is obtained for $\mathrm{CuS} / \mathrm{PbS} / \ldots / \mathrm{CuS} / \mathrm{PbS}$ structures

19 with 8 SILAR cycles (2.54\% efficiency) but the fill factor is 0.36 which is low in comparison to the fill factors values which are normally observed in QDSCs. According 
1 to Figure $5 \mathrm{~b}$, the dark current is enhanced for the samples with 10 or 12 SILAR cycles

2 which leads to lower efficiencies according to Table 4. Figure 6a indicates the SEM

3 micrograph from the $\mathrm{CuS} / \mathrm{PbS} / \ldots / \mathrm{CuS} / \mathrm{PbS}(8 \mathrm{~S}) \mathrm{CEs}$ which are prepared on the FTO

4 substrates by SILAR method. The structure of the CuS CEs which are made on the

5 metallic brass substrates is indicated in Figure $6 \mathrm{~b}$ for comparison.

6

7 According to this figure; $\mathrm{CuS} / \mathrm{PbS} / . . / \mathrm{CuS} / \mathrm{PbS} \mathrm{CE}$ has a compact structure in 8 comparison to the CEs which are made on metallic substrates (figure 6b) which could

9 decrease the interface area between the $\mathrm{CE}$ and electrolyte which consequently restricts 10 the charge transfer at CE/electrolyte interface. Restricted charge transfer at the $11 \mathrm{CE} /$ Electrolyte interface, accumulates space charges and therefore creates s-shaped

Figure 6. deformations in the current voltage characteristics (as it is seen for $\mathrm{CuS} / . . / \mathrm{PbS}(6)$ and $\mathrm{CuS} / . . / \mathrm{PbS}(8 \mathrm{~S}) \mathrm{CEs}$ in the figure 5a) of the cells [46, 47]. As a result, performance of the cells decreases by diminishing fill factor (Figure 5 and Table 4) considerably. Regarding the low fill factors for $\mathrm{CuS} / . . . / \mathrm{PbS} \mathrm{CEs}$ (table 3) and their compact structure (Figure 6a), graphene was pre deposited on the FTO substrates before $\mathrm{CuS}$ and $\mathrm{PbS}$ deposition, in order to enhance the performance of CEs. Graphene was spin coated on the FTO substrates and then $\mathrm{CuS}$ and $\mathrm{PbS}$ layers were deposited on the FTO/G substrates as explained in the experimental section.

Figure 7 indicates the current-voltage properties of the cells which are made by deposition of $\mathrm{CuS} / \mathrm{PbS} / . . / \mathrm{CuS} / \mathrm{PbS} \mathrm{CEs}$ on the $\mathrm{FTO} /$ graphene substrates, under light (Figure 7a) and dark conditions (Figure 7b). Here graphene was spin coated 2 times in all samples and the number of $\mathrm{CuS} / . . / \mathrm{PbS}$ deposited layers was varied from 6 to 12 cycles.

Figure 7. 
1 For a more clear investigation, open circuit voltage $\left(\mathrm{V}_{\mathrm{oc}}\right)$, short circuit current density

$2\left(\mathrm{~J}_{\mathrm{sc}}\right)$, fill factor $(\mathrm{FF})$, and conversion efficiency $(\mathrm{E})$ are shown in Table 5.

3

\begin{tabular}{ccccc}
\hline Cathode Type & $\mathrm{V}_{\mathrm{oc}}(\mathrm{mV})$ & $\mathrm{J}_{\mathrm{sc}}\left(\mathrm{mA} / \mathrm{cm}^{2}\right)$ & $\mathrm{FF}$ & $\mathrm{E}(\%)$ \\
\hline $\mathrm{G}(2) / \mathrm{CuS} / \mathrm{PbS} / \ldots / \mathrm{CuS} / \mathrm{PbS}(6 \mathrm{~S})$ & 520 & 11.11 & 0.43 & 2.48 \\
$\mathrm{G}(2) / \mathrm{CuS} / \mathrm{PbS} / \ldots / \mathrm{CuS} / \mathrm{PbS}(8 \mathrm{~S})$ & 550 & 11.43 & 0.51 & 3.21 \\
$\mathrm{G}(2) / \mathrm{CuS} / \mathrm{PbS} / \ldots / \mathrm{CuS} / \mathrm{PbS}(10 \mathrm{~S})$ & 495 & 9.40 & 0.45 & 2.09 \\
$\mathrm{G}(2) / \mathrm{CuS} / \mathrm{PbS} / . . . \mathrm{CuS} / \mathrm{PbS}(12 \mathrm{~S})$ & 429 & 8.11 & 0.40 & 1.39 \\
\hline
\end{tabular}

8

9 Here the best performance of the cells is obtained for $\mathrm{G}(2) / \mathrm{CuS} / \mathrm{PbS} / \ldots / \mathrm{CuS} / \mathrm{PbS}$ (8S)

10 structures $(3.21 \%)$ which is more than the cells without pre deposition of graphene and

11 the same cycles of $\mathrm{CuS} / \mathrm{PbS} / . . / \mathrm{CuS} / \mathrm{PbS}$ structure (2.54\% efficiency) according to

12 Tables 4 and 5. According to Figure 7b, the cells with $\mathrm{G}(2) / \mathrm{CuS} / \mathrm{PbS} / \ldots / \mathrm{CuS} / \mathrm{PbS}(8 \mathrm{~S})$

13 CEs have the lowest dark current which is in agreement with their best performance 14 under light condition. Also the fill factor is 0.51 in the case of $15 \mathrm{G}(2) / \mathrm{CuS} / \mathrm{PbS} / \ldots / \mathrm{CuS} / \mathrm{PbS}(8 \mathrm{~S})$ CEs (Table 5) which has improved in comparison to 16 the $\mathrm{CuS} / \mathrm{PbS} / \ldots / \mathrm{CuS} / \mathrm{PbS}(8 \mathrm{~S}) \mathrm{CEs}$ with the fill factor of 0.36 (table 4). If we compare 17 the fill factors of the each $\mathrm{CuS} / \ldots$ / PbS CE structures in the table 4 with the fill factors 18 of the $\mathrm{CEs}$ that have a same number of deposited $\mathrm{CuS} / \ldots / \mathrm{PbS}$ layers but have a pre 19 deposited graphene layer (Table 5), a systematic enhancement in the fill factors could be 20 observed in case of graphene pre deposited layers. These results indicates that the 
1 performance of SILAR deposited CEs could systematically enhanced by graphene pre 2 deposition on the FTO substrate. Figure 8 indicates the SEM micrograph of

$3 \mathrm{G}(2) / \mathrm{CuS} / \ldots / \mathrm{PbS}(8 \mathrm{~S}) \mathrm{CEs}$. From this figure it can be seen that the morphology of the 4 layer is completely different in comparison to the $\mathrm{CuS} / \ldots / \mathrm{PbS}(8 \mathrm{~S}) \mathrm{CEs}$ (figure 6a).

\section{Figure 8.}

6 Comparison between figure $6 \mathrm{a}$ and 8 indicates that the compact structure of the

$7 \mathrm{CuS} / . . . / \mathrm{PbS}$ structure (figure 6) converts to a more porous structure after graphene pre 8 deposition on the FTO substrate (figure 8). The schematic structure of the various CEs 9 without and with graphene pre deposition is presented in figure 9a and $9 \mathrm{~b}$ respectively.

\section{Figure 9.}

11 According to this scheme more porous structures are obtained by graphene pre 12 deposition in comparison to conventional FTO coated $\mathrm{CuS} / . . / \mathrm{PbS}$ CEs. The more 13 porosity could increase the CEs surface area which consequently, improves the charge 14 transfer at the CE/electrolyte interface noticeably. The improvement in the charge 15 transfer at the $\mathrm{CE} /$ electrolyte interface decreases the internal resistance and 16 concentration gradients of the redox species in the electrolyte, parameters that could 17 strongly affect the fill factor. This is confirmed by the improved fill factors that are 18 obtained in $\mathrm{G} / \mathrm{CuS} / \ldots / \mathrm{PbS}$ structures (table 5 ) compared to the $\mathrm{CuS} / \ldots / \mathrm{PbS}$ structures 19 (table 4) as it was explained before. According to the present results, an improvement in 20 the efficiency of QDSCs, especially fill factors, is obtained by applying the pre 21 deposited graphene on the FTO substrate and improving the porosity of the CE. From 22 the present study, it can be concluded that the performance of the conventional SILAR 23 deposited CEs could be simply enhanced by graphene pre deposition on the FTO 24 substrates. 


\section{4. Conclusions}

2 Here, the graphene pre deposition method was introduced for modifying the current CEs

3 which are generally used in QDSCs. For the CdS/CdSe QD sensitized cells and G/

$4 \mathrm{CuS} / \ldots / \mathrm{PbS}$ CEs, the cell performance with $3.21 \%\left(\mathrm{~V}_{\mathrm{oc}}=550 \mathrm{mV}, \mathrm{J}_{\mathrm{sc}}=11.43 \mathrm{~mA} / \mathrm{cm}^{2}\right.$,

$5 \quad \mathrm{FF}=0.51$ ) efficiency was obtained which was enhanced compared with the photovoltaic

6 properties of the cells with $\mathrm{CuS} / \ldots . \mathrm{PbS}$ CEs with $2.54 \%$ efficiency $\left(\mathrm{V}_{\text {oc }}=526 \mathrm{mV}\right.$,

$\left.7 \mathrm{~J}_{\mathrm{sc}}=13.4 \mathrm{~mA} / \mathrm{cm}^{2}, \mathrm{FF}=0.36\right) . \mathrm{SEM}$ results indicated that the compact structure of the

8 conventional $\mathrm{CuS} / . . / \mathrm{PbS} \mathrm{CEs}$ converts to a more porous structure by a simple graphene

9 pre deposition on the FTO substrates. We showed that the G pre deposition method

10 could offer new opportunities for the simple improving the performance of the solution-

11 processed CEs with considerable performance in polysulfide redox electrolytes.

13 Figure and Table Captions:

14

Figure 1. SEM micrograph from transparent (a) and scattering layer (b), scale bars are $500 \mathrm{~nm}$ and 1 micron for figure $1 \mathrm{a}$ and $1 \mathrm{~b}$ respectively.

Figure 2. SEM micrograph from graphene sheets on the FTO substrates, scale bars is $500 \mathrm{~nm}$ and arrows indicate the non uniformities on the surface

Figure 3: Current-voltage characteristic of cells with $\mathrm{G}(1) / \mathrm{PbS}(6), \mathrm{G}(2) / \mathrm{PbS}(6), \ldots, \mathrm{G}(12) / \mathrm{PbS}(6 \mathrm{~S})$ counter electrodes at AM 1.5 ligh illumination (a) and dark condition (b).

Figure 4: Current-voltage characteristic of the cells with $\mathrm{G}(2), \mathrm{PbS}(6 \mathrm{~S})$ and $\mathrm{G}(2) / \mathrm{PbS}(6 \mathrm{~S})$ counter electrodes at AM 1.5 ligh illumination

Figure 5: Current-voltage characteristic of the cells with $\mathrm{CuS} / \mathrm{PbS} / \ldots \mathrm{CuS} / \mathrm{PbS} \mathrm{CEs}$ structures at AM 1.5 ligh illumination (a) and dark condition (b). 
1 Figure 6. $\mathrm{SEM}$ micrograph from $\mathrm{CuS} / \mathrm{PbS} / . . / \mathrm{CuS} / \mathrm{PbS}(8 \mathrm{~S}) \mathrm{CEs}$ which are deposited on the FTO substrates (a), SEM micrograph from CuS CEs which are made on the metallic brass substrates, scale bars is $500 \mathrm{~nm}$ in figure a and 2 microns in figure $\mathrm{b}$.

4 Figure 7: Current-voltage characteristic of the cells with $\mathrm{G}(2) / \mathrm{CuS} / . . / \mathrm{PbS}(6 \mathrm{~S}), \mathrm{G}(2) / \mathrm{CuS} / . . / \mathrm{PbS}(8 \mathrm{~S}), .$. , $\mathrm{G}(2) / \mathrm{CuS} / . . / \mathrm{PbS}(12 \mathrm{~S})$ counter electrodes at $\mathrm{AM} 1.5$ ligh illumination (a) and dark condition (b).

6 Figure 8. SEM micrograph from $\mathrm{G}(2) / \mathrm{CuS} / \mathrm{PbS} / . . \mathrm{CuS} / \mathrm{PbS}(8 \mathrm{~S}) \mathrm{CEs}$, scale bars is $500 \mathrm{~nm}$

7 Figure 9: Schematic structure of the $\mathrm{CuS} / \ldots / \mathrm{PbS}$ CEs without (a) and with graphene pre deposition on 8 the FTO substrate (b)

9 Table 1: Photovoltaic parameters of the QDSCs prepared and analyzed: photocurrent $j_{s c}$, open circuit

10 voltage $V_{o c}$, fill factor $F F$, and efficiency $E$, as a function of the CEs structure tested under standard 11 conditions $\left(100 \mathrm{~mW} / \mathrm{cm}^{2}\right.$ AM $\left.1.5 \mathrm{G}\right)$.

12 Table 2: Photovoltaic parameters of the QDSCs prepared and analyzed: photocurrent $j_{s c}$, open circuit 13 voltage $V_{o c}$, fill factor $F F$, and efficiency $E$, as a function of aging time.

14 Table 3: Photovoltaic parameters of the QDSCs prepared and analyzed: photocurrent $j_{s c}$, open circuit 15 voltage $V_{o c}$, fill factor $F F$, and efficiency $E$, as a function of the CEs structure

16 Table 4: Photovoltaic parameters of the QDSCs prepared and analyzed: photocurrent $j_{s c}$, open circuit voltage $V_{o c}$, fill factor $F F$, and efficiency $E$, as a function of the CEs structure.

Table 5: Photovoltaic parameters of the QDSCs prepared and analyzed: photocurrent $j_{s c}$, open circuit voltage $V_{o c}$, fill factor $F F$, and efficiency $E$, as a function of the CEs structure tested under standard conditions (100 mW/cm² AM 1.5G).

\section{Acknowledgements:}

22 This work was financially supported by Iran National Science Foundation.

\section{References}

25 [1] Y.L Lee and Y.S Lo, Advanced Functional Materials, 2009, 19(4), 604-609.

26 [2] J. H Im, C. R Lee, J. W Lee, S. W Park and N. G Park, Nanoscale, 2011, 3(10), 
$1 \quad 4088-4093$.

2 [3] P.V. Kamat, Journal of Physical Chemistry C, 2008,112, 18737-18753.

3 [4] M. Samadpour, Z. Ghane, N. Ghazyani, F. Tajabadi and N. Taghavinia, Journal of

4 Physics D: Applied Physics, 2013, 46, 485101.

5 [5] M. Samadpour and M. Molaei, Chinese Physics B, 2014, 23(4), 047302.

6 [6] Z. Huang, X. Zou and H. Zhou, Materials Letters, 2013, 95, 139-141.

7 [7] X. Y. Yu, J. Y. Liao, K. Q. Qiu, D. B. Kuang and C. Y. Su, ACS Nano, 2011, 5(12),

$8 \quad 9494-9500$.

9 [8] S. Rühle, M. Shalom and A. Zaban, ChemPhysChem, 2010, 11, 2290-2304.

10 [9] A. J Nozik, Physica E: Low-dimensional Systems and Nanostructures, 2002, 14(1), $11 \quad 115-20$.

12 [10] S. Arabzade, M. Samadpour and N. Taghavinia, RSC Advances, 2015, 5(57), $13 \quad 45592-45598$.

14 [11] A.P. Alivisatos, Science, 1996, 271, 933-937.

15 [12] W.W. Yu, L. Qu, W. Guo and X. Peng, Chemistry of Materials, 2003, 15, 2854162860.

17 [13] M.C. Beard, J.M. Luther, O.E. Semonin and A.J. Nozik, Accounts of Chemical 18 Research, 2013, 46, 1252-1260.

19 [14] H. Wang, Y. Bai, H. Zhang, Z. Zhang, J. Li and L.Guo, The Journal of Physical 20 Chemistry C, 2010, 114(39), 16451-16455.

21 [15] Z. Li, L. Yu, Y. Liu and S. Sun, Electrochimica Acta, 2015, 153, 200-209.

22 [16] W.Lee, S. K. Min, V. Dhas, S. B. Ogale and S. H. Han, Electrochemistry 23 Communications, 2009, 11(1), 103-106.

24 [17] X. F. Gao, H. B. Li, W. T. Sun, Q. Chen, F. Q. Tang and L. M. Peng, The Journal 25 of Physical Chemistry C, 2009, 113(18), 7531-7535.

26 [18] Y. L. Lee and C. H. Chang, Journal of Power Sources, 2008, 185(1), 584-588.

27 [19] L. Li, X. Yang, J. Gao, H. Tian, J. Zhao, A. Hagfeldt and L. Sun, Journal of the 28 American Chemical Society, 2011, 133(22), 8458-8460.

29 [20] B. Fang, M. Kim, S. Q. Fan, J. H. Kim, D. P. Wilkinson, J. Ko and J. S. Yu, 30 Journal of Materials Chemistry, 2011, 21(24), 8742-8748.

31 [21] K. Zhao, Z. Pan, I. Mora-Seró, E. Cánovas, H. Wang, Y. Song and X. Zhong, 32 Journal of the American Chemical Society, 2015, 137(16), 5602-5609. 
1 [22] Z. Ren, J. Wang, Z. Pan, K. Zhao, H. Zhang, Y. Li, Y. Zhao, I. Mora-Sero, J.

2 Bisquert and X. Zhong, Chemistry of Materials, 2015, 27(24), 8398-8405.

3 [23] P. Sudhagar, T. Song, D. H. Lee, I. Mora-Seró, J. Bisquert, M. Laudenslager, W.M.

4 Sigmund, W.I. Park, U. Paik and Y.S. Kang, The Journal of Physical Chemistry Letters,

5 2011, 2, 1984-1990.

6 [24] Z. Huang, X. Zou and H. Zhou, Materials Letters, 2013, 95, 139-141.

7 [25] P. Parand, M. Samadpour, A. Esfandiar and A. Iraji Zad, ACS Photonics, 2014, 1, $8 \quad 323-330$.

9 [26] V. González-Pedro, X. Xu, I. Mora-Seró and J. Bisquert, ACS Nano, 2010, 4, 5783 105790.

11 [27] B. O'Regan and M. Grätzel, Nature, 1991, 353, 737-740.

12 [28] Y. Chiba, A. Islam, Y. Watanabe, R. Komiya, N. Koide and L. Han, Japanese

13 Journal of Applied Physics, Part 2: Letters, 2006, 45, L638-L640.

14 [29] Z.S. Wang, H. Kawauchi, T. Kashima and H. Arakawa, Coordination Chemistry

15 Reviews, 2004, 248, 1381-1389.

16 [30] E. Ramasamy, W.J. Lee, D.Y. Lee and J.S. Song, Electrochemistry

17 Communications, 2008,10, 1087-1089.

18 [31] Z. Yang, C.Y. Chen, C.W. Liu, C.L. Li and H.T. Chang, Advanced Energy

19 Materials, 2011, 1, 259-264.

20 [32] S.Q. Fan, B. Fang, J.H. Kim, J.J. Kim, J.S. Yu and J. Ko, Applied Physics Letters, $212010,96(6), 063501$.

22 [33] L. Li, P. Zhu, S. Peng, M. Srinivasan, Q. Yan, A.S. Nair, B. Liu and S.

23 Samakrishna, Journal of Physical Chemistry C, 2014, 118, 16526-16535.

24 [34] H.J. Kim, J.H. Kim, C.H.S.S. Pavan Kumar, D. Punnoose, S.K. Kim, C.V.V.M.

25 Gopi and S. Srinivasa Rao, Journal of Electroanalytical Chemistry, 2015,739, 20-27.

26 [35] V.D. Dao, Y. Choi, K. Yong, L.L. Larina, O. Shevaleevskiy and H.S. Choi, Journal 27 of Power Sources, 2015, 274, 831-838.

28 [36] Y. Chen, X. Zhang, Q. Tao, W. Fu, H. Yang, S. Su, Y. Mu, L. Zhou and M. Li, 29 RSC Advances, 2015, 5,1835-1840.

30 [37] J. G. Radich, R. Dwyer and P. V. Kamat, The Journal of Physical Chemistry

31 Letters, 2011, 2(19), 2453-2460.

32 [38] M. Seol, E. Ramasamy, J. Lee and K. Yong, The Journal of Physical Chemistry C, 
$1 \quad 2011, \mathbf{1 1 5 ( 4 4 ) ,}, 22018-22024$.

2 [39] F. Wang, H. Dong, J. Pan, J. Li, Q. Li and D. Xu, Journal of Physical Chemistry C, 3 2014,118, 19589-19598.

4 [40] C. Y. Lin, C. Y. Teng, T. L. Li, Y. L. Lee and H. Teng, Journal of Materials

5 Chemistry A, 2013, 1, 1155-1162.

6 [41] Z. Tachan, M. Shalom, I. Hod, S. Rühle, S. Tirosh and A. Zaban, The Journal of

7 Physical Chemistry C, 2011, 115, 6162-6166.

8 [42] M. Samadpour, P.P. Boix, S. Giménez, A. Iraji Zad, N. Taghavinia, I. Mora-Seró

9 and J. Bisquert, The Journal of Physical Chemistry C, 2011, 115, 14400-14407.

10 [43] A. Braga, S. Giménez, I. Concina, A. Vomiero and I. Mora-Seró, The Journal of

11 Physical Chemistry Letters, 2011, 2(5), 454-460.

12 [44] N. Balis, V. Dracopoulos, K. Bourikas and P. Lianos, Electrochimica Acta, 2013, 13 91, 246-252.

14 [45] M. Eskandari, V. Ahmadi and R. Ghahary, Electrochimica Acta, 2015,151, 393 15398.

16 [46] A. Wagenpfahl, D. Rauh, M. Binder, C. Deibel and V. Dyakonov, Phys. Rev. B, $172010,82,115306$.

18 [47] B. Julian, V. Brault, S. Ahmad, L. Breau, M. K. Nazeeruddin, B. Marsan, S. M.

19 Zakeeruddin and M. Grätzel, Energy \& Environmental Science, 2012, 5, 6089-6097.

20 [48] S. Ito, P. Chen, P. Comte, M.K. Nazeeruddin, P. Liska, P. Péchy and M. Grätzel,

21 Progress in Photovoltaics: Research and Applications, 2007, 15, 603-612.

22 [49] N. Ghazyani, M.H. Majles Ara, F. Tajabadi, A. Dabirian, R. Mohammadpour and

23 N. Taghavinia, RSC Advances, 2014, 4, 3621-3626.

24 [50] M. Samadpour, S. Giménez, P.P. Boix, Q. Shen, M.E. Calvo, N. Taghavinia, A.

25 Iraji Zad, T. Toyoda, H. Míguez and I. Mora-Seró, Electrochimica Acta, 2012,75, 13926147.

27 [51] Q. Shen, J. Kobayashi, L.J. Diguna and T. Toyoda, Journal of Applied Physics, $282008, \mathbf{1 0 3}, 084304$

29

30 

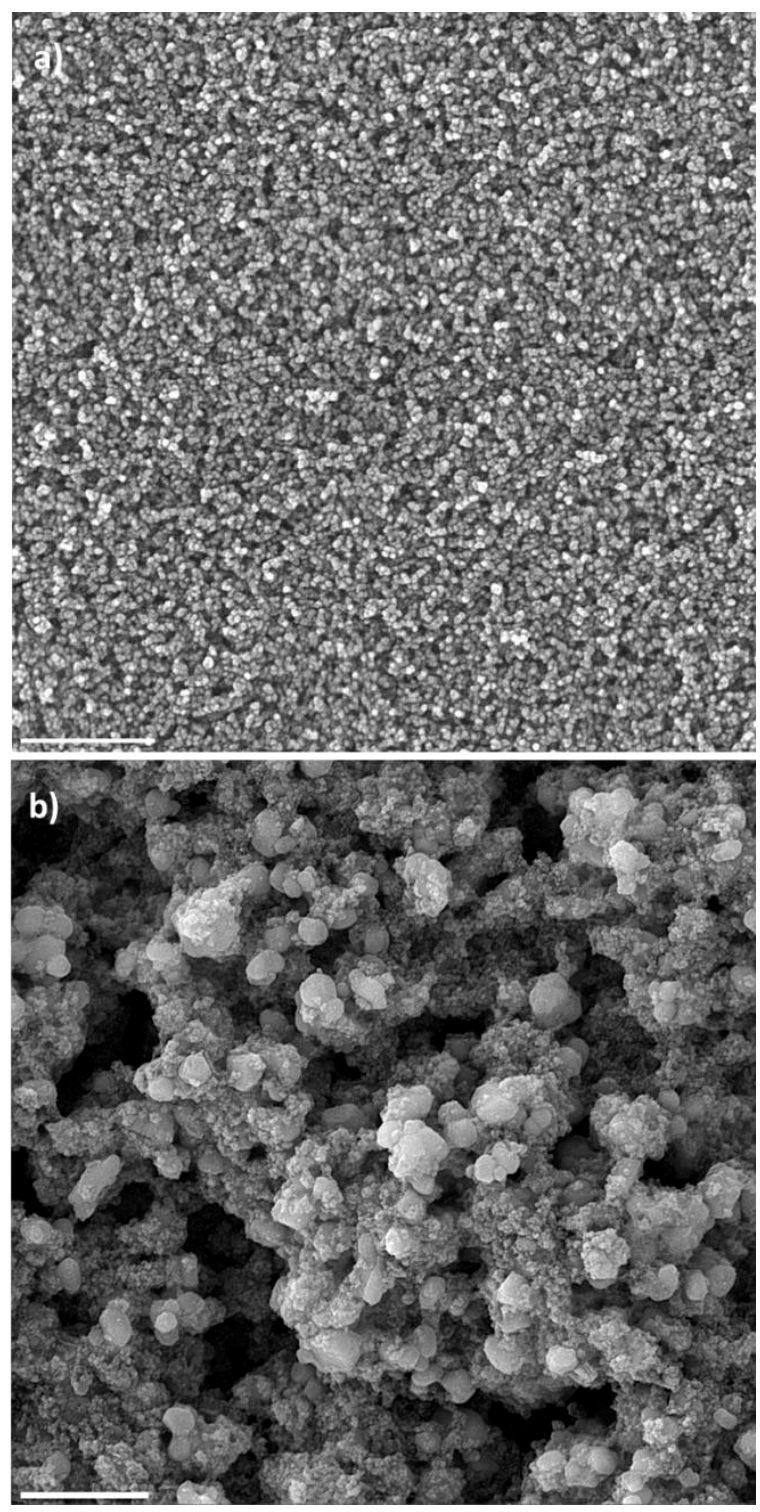

Figure 1. 


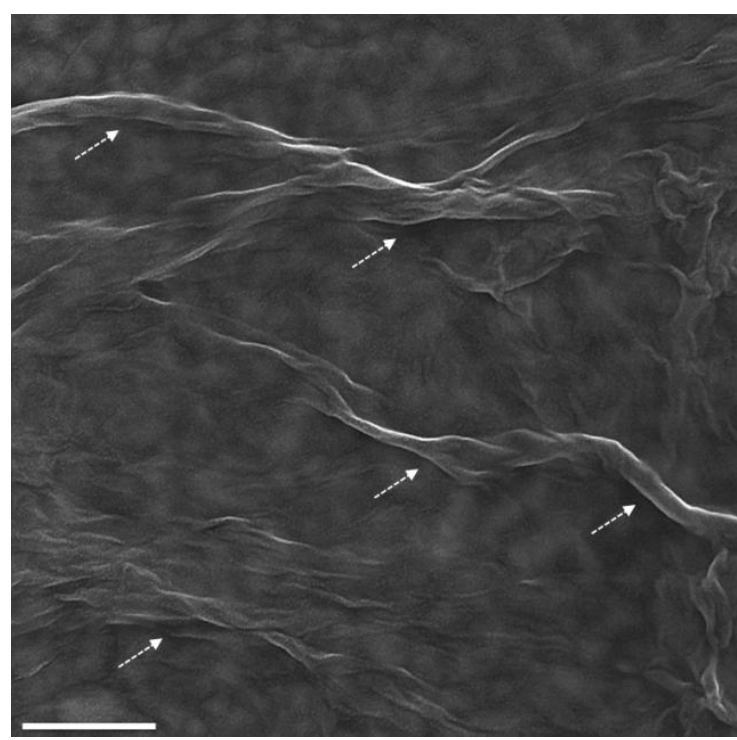

Figure 2.
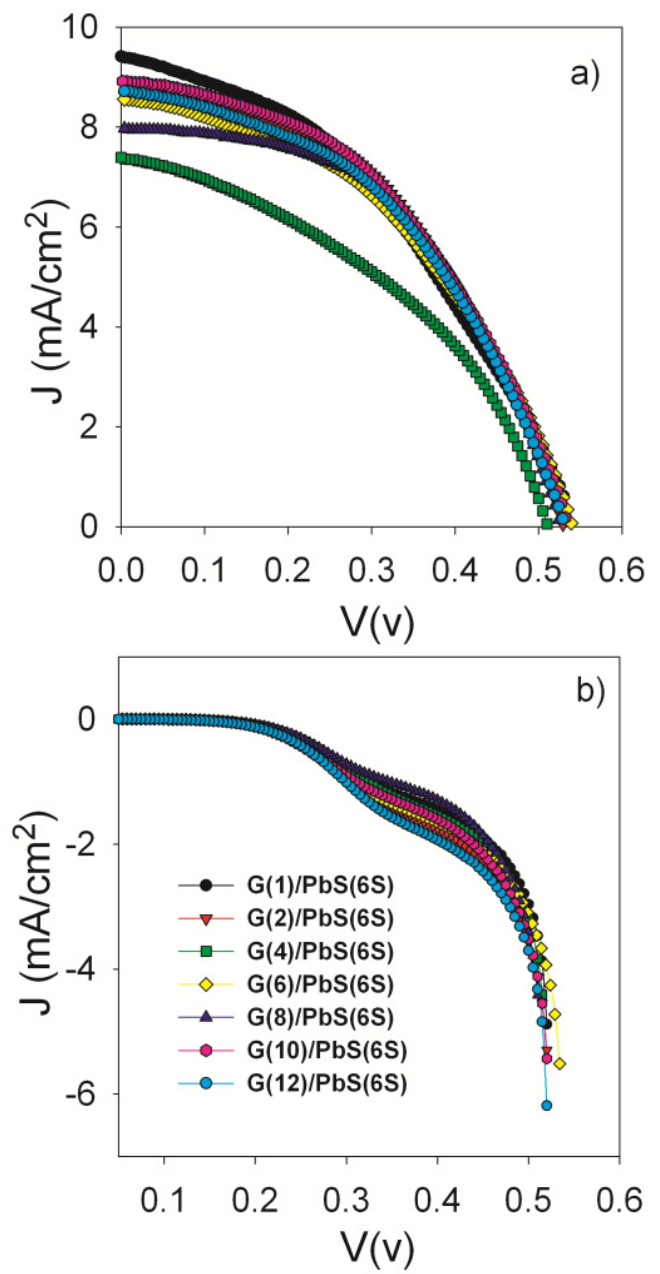
2

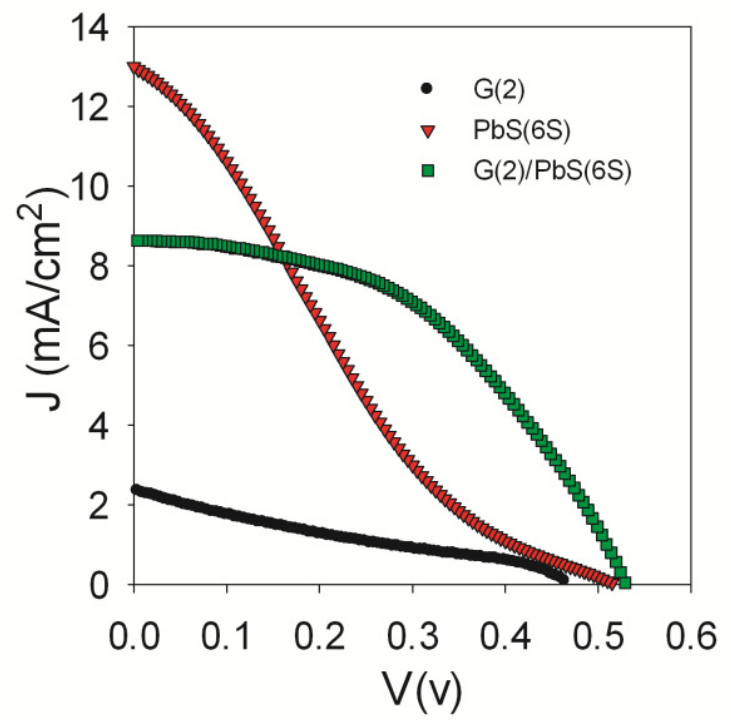

Figure 4 .

5

6

7 

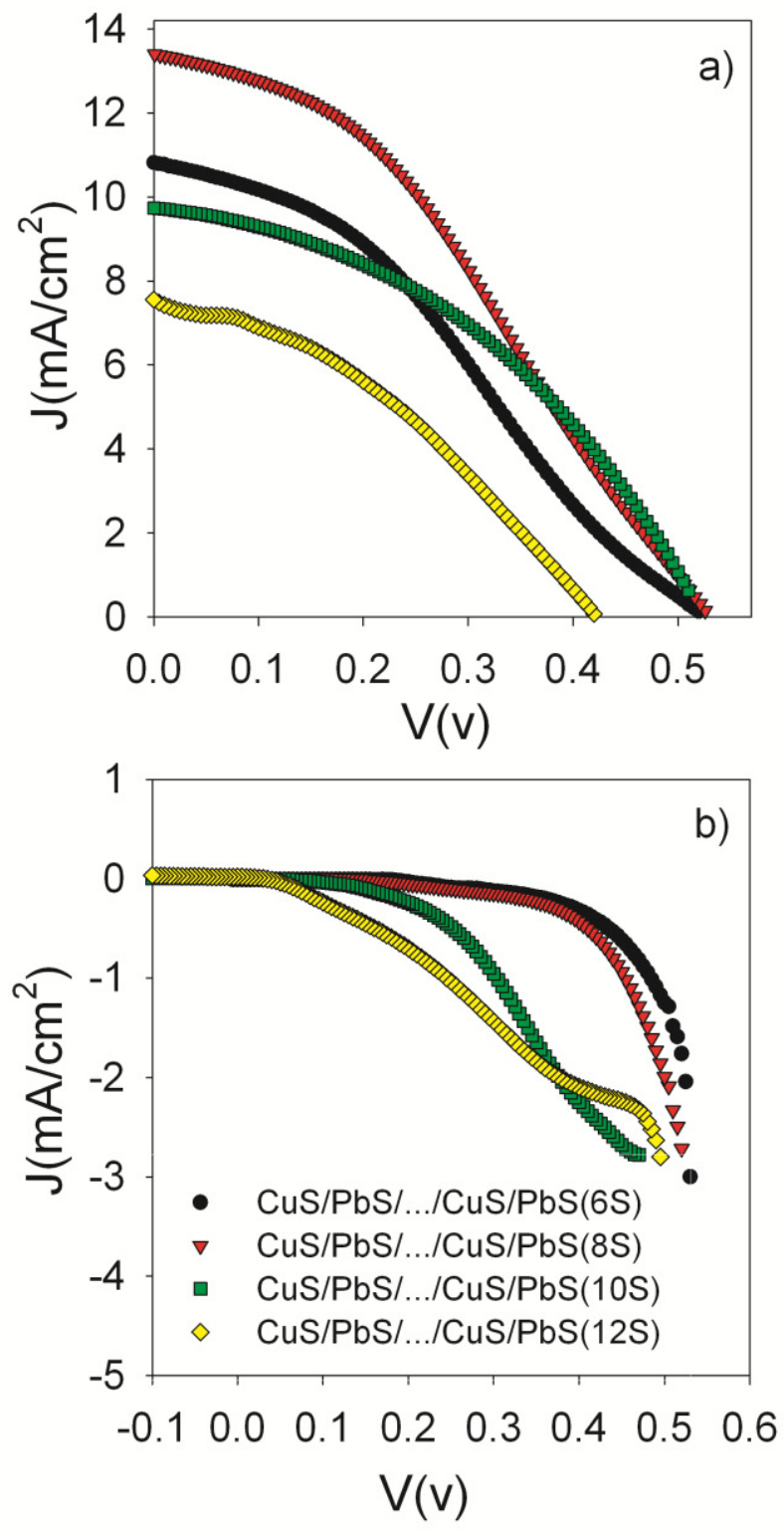

Figure 5. 

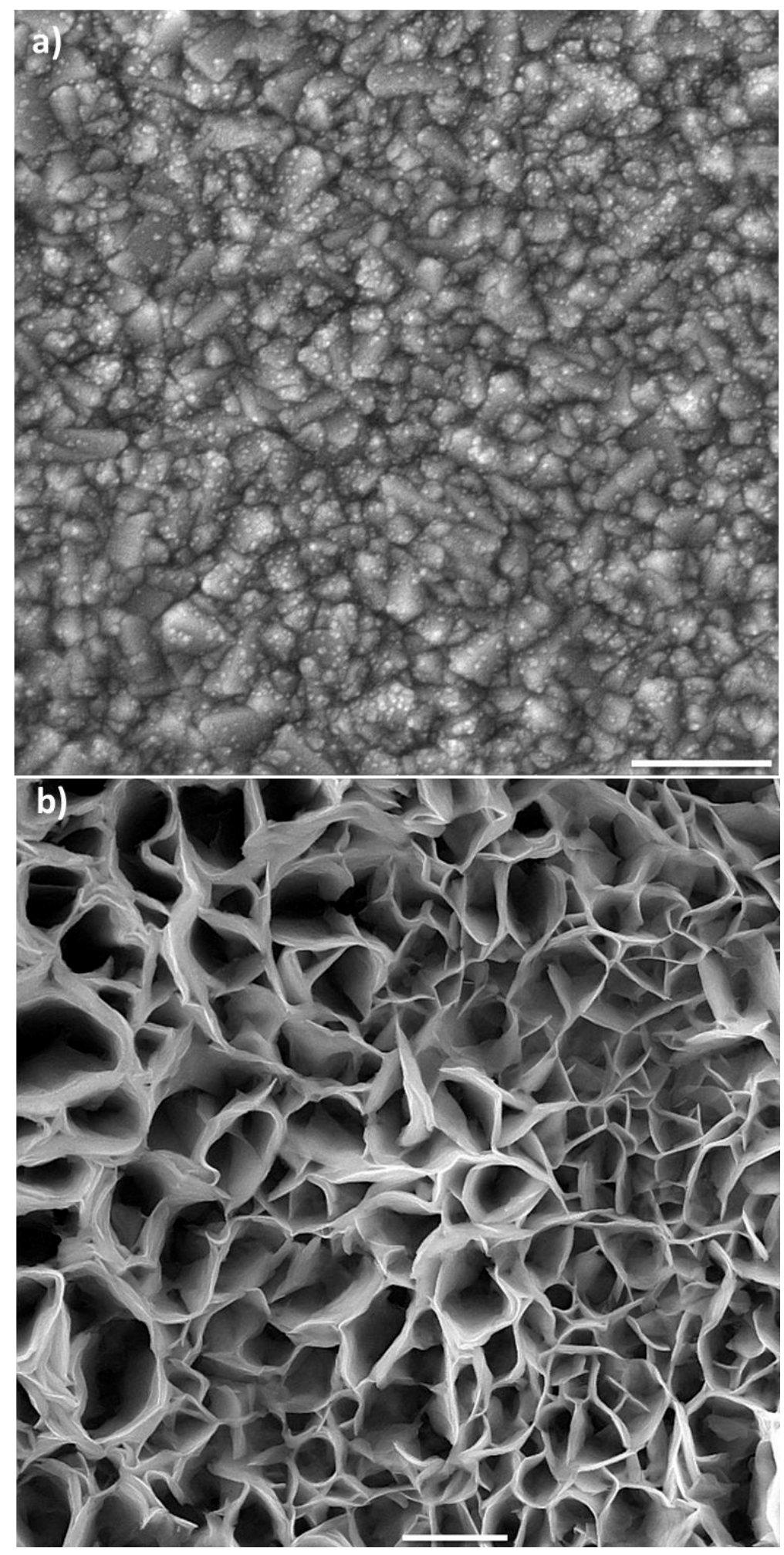

Figure 6. 

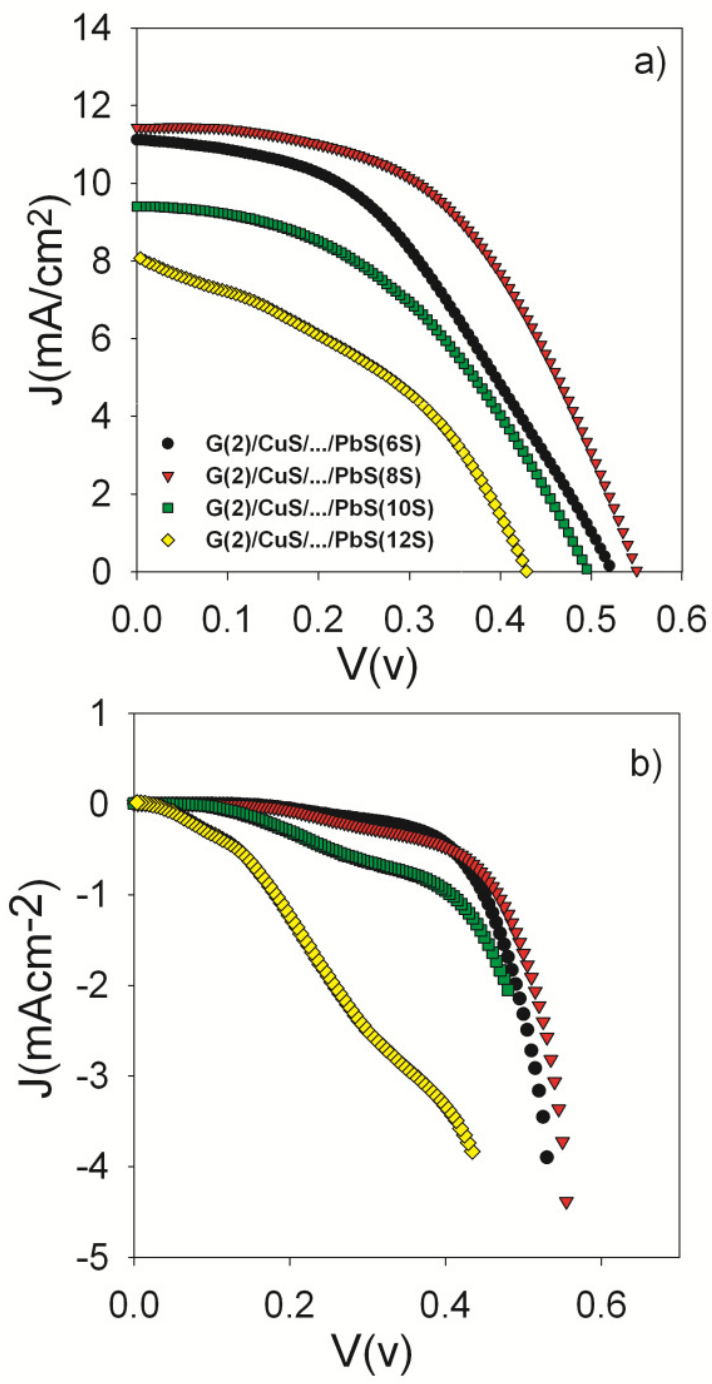

Figure 7. 


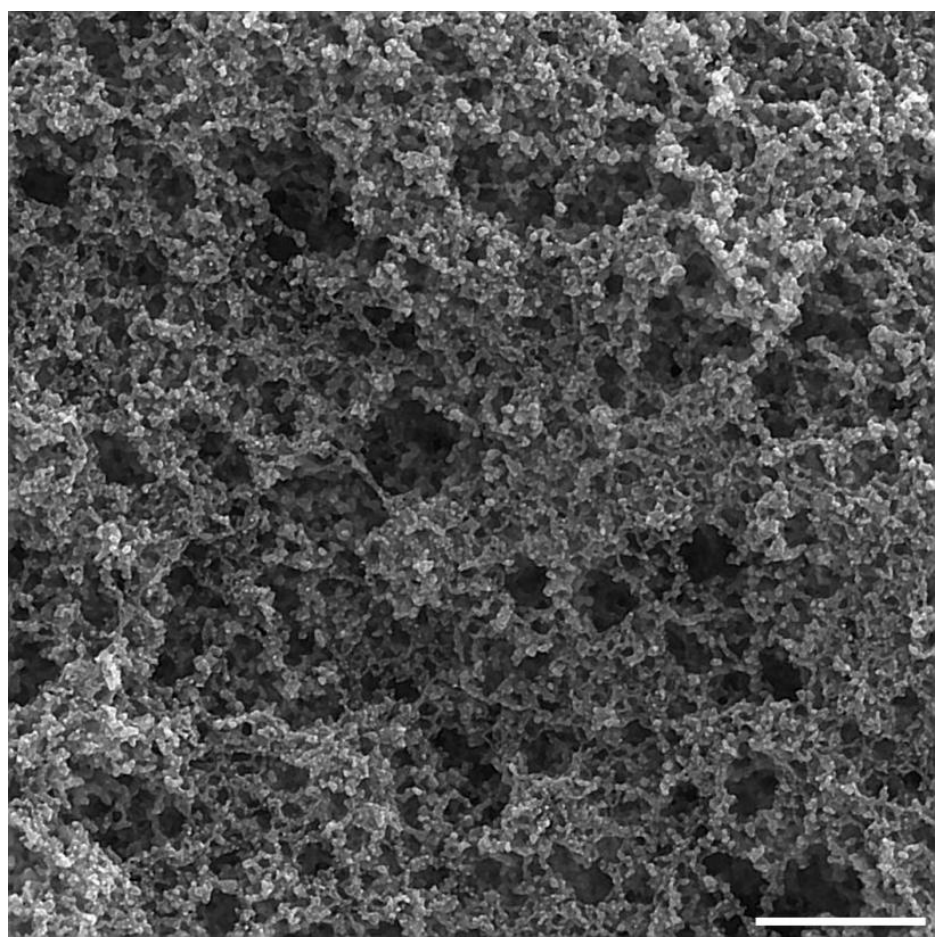

Figure 8.

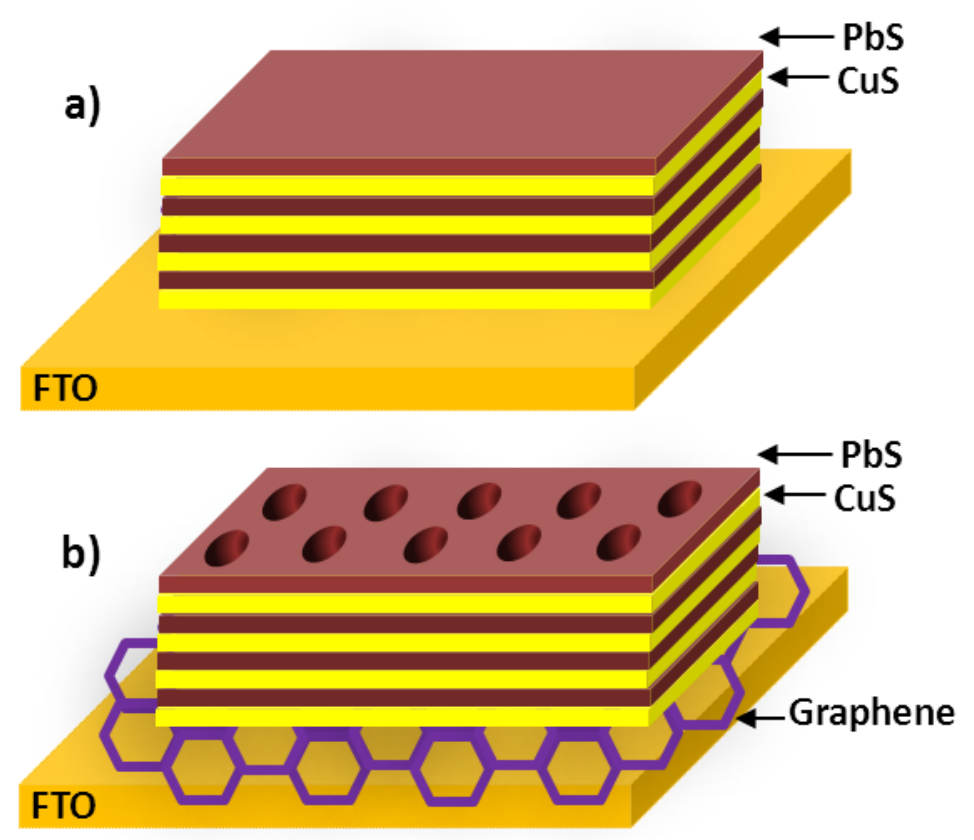

4

Figure 9.

6 